\title{
Könyvszemle
}

SIPOS JÚLIA GONDOZÁSÁBAN

\section{A SZOCIÁLIS SZOLGÁLTATÁSOKHOZ VALÓ HOZZÁFÉRÉS VIDÉKEN Társadalmi kérdések gazdasági prizmában}

A „LOSS” (Local Organization of Social Services) a Helyi Szociálisellátó Szervezetek nemzetközi összehasonlító kutatásának rövidítése, amely 1993-ban jött létre. A hálózatot Rainer Greca (Ingolstadti Katolikus Egyetem) és Thomas R. Lawson (University of Louisville) kezdeményezték Münchenben több európai kutatóintézet bevonásával.

A LOSS-kutatás lefedi a helyi közösségi színterekben létrejött szociális ellátás egészét. Magában foglalja a közösségek szociális rendszerét, az emberi erőforrás termelésének és megőrzésének intézményi elemeit, beleértve a spontán, nem formális társadalmi cselekvéseket is. A LOSS átfogja az oktatási és képzési rendszereket, az egészségügyi ellátást, a közvetlen és közvetett szociális támogatást, valamint a tudástermelés intézményeit.

A közel három évtized alatt számos magyar, német és angol nyelvü kötet jelent meg. Az egyik kötet Finnország és Magyarország összehasonlítására vállalkozott, különös tekintettel a vidéki életterekre (Access to Services in Rural Areas: A Comparison of Finland and Hungary). A könyv egyik ambíciója az volt, hogy két regionális metszet segítségével mutassa be a két ország két hátrányos helyzetü régiójának életét. A könyv másik jellemzője a sajátos megközelítése: a társadalmi kérdéseket egy mikroökonómiai prizmán keresztül tárja az olvasó elé (Toward a Dynamic Theory of Local Organization of Social Services, LOSS).

A kinálat és kereslet egyensúlya mint értelmezési keret, jelentős szerepet kap a LOSS-modellben. A helyi szociális szolgáltatások rendszerét egy piacnak tekintik, amely a szolgáltatók és az ügyfelek között müködik. A helyi szociális szolgáltatások fö önálló szektorai - a közoktatás, az egészségügyi ellátórendszer és a szociális támogatási rendszer - a kínálati oldalt képviselik, s ezzel szemben a helyi társadalom képezi a keresleti oldalt, amelyben az ügyfelek a szolgáltatásokat keresik. A LOSS rendszere szimmetrikus vagy aszimmetrikus lehet. Szimmetrikus, amikor keresleti és kínálati oldala kiegyensúlyozott, amikor a növekvő társadalmi igényeket a kínálati oldal növekvő kapacitása kiszolgálja. A modell aszimmetrikus, amikor a szociális szükségletekre nincs megfelelő válasz a kínálati oldalon. 
Amennyiben a LOSS elégséges szinten müködik, akkor lehetővé válik a helyi társadalmak számára a társadalmi válságok elviselése. Ez a védelmi rendszer tette elviselhetővé a II. világháború utáni Európában a gazdasági válságokat. Segítette, hogy az eltérő nemzeti politikák mérsékelt keretek között maradjanak.

A tétel bizonyítására Magyarország 18. századi humán befektetéseit említi, amelyek kölcsönösen összefüggtek az ország gazdasági fejlődésével és a demográfiai fellendüléssel, amikor a népesedési dinamika az Újvilág népesedési üteméhez volt hasonló. Az említett demográfiai fellendülés azért következett be, mert a szociális szolgáltatások, így az iskolák létrehozása kiszolgálta a növekvő népesség igényeit, és szolgálta annak jólétét. A történelmi léptékü eredmények ritkábban jelentkeznek az adott jelenben, inkább a következő nemzedékek számára adnak erőt. A második jó példa, amely rámutat a magyarországi LOSS fejlődésére, az úgynevezett konszolidációs időszakra tehető. Ezekben az években az ország minden idők legnagyobb állami oktatási befektetését valósította meg, amely Klebelsberg Kuno nevéhez kötődött. A klebelsbergi program megalapozta a modern kort, annak humán erőforrás-kínálatát, amely nélkül Magyarország a 20. század kihívásaira nem tudott volna megfelelő módon válaszolni.

A könyv részletes empirikus elemzéseket is közöl. Ilyen például az idősek szolgáltatási hozzáférése Magyarországon, melyet Patyán László és Fábián Gergely ismertetnek (Characteristic of Elderly People's Access to Social Services). A szerzők olyan kérdésekre összpontosítanak, mint például a minőségi szolgáltatások nyújtása, az egyenlő és a megfelelő hozzáférés biztosításának módja, figyelembe véve, hogy az idős emberek az EU szolgáltatáspolitikájának, több ok miatt, a legkritikusabb célcsoportjaivá váltak. Az egyik legfontosabb kérdés, amit Patyán László és Fábián Gergely a középpontba helyez, az idősek ellátása és a szociális szolgálatok igénybevétele. A szerzők megfigyelték, hogy nehézségek merülhetnek fel, ha egy idős ember nem rendelkezik információval a rendeletekről vagy a jogosultságról, vagy ha szégyelli, hogy segítségért folyamodik, vagy fogyatékosság miatt nem férhet hozzá az amúgy őt megillető szolgáltatásokhoz.

A szerzők az OTKA által támogatott MTA Társadalomtudományi Kutatóközpont felméréseire építenek, amelyeket szondák, kérdőíves lekérdezések támasztanak alá. Megállapítják, hogy Magyarország keleti részén, amely általában kevésbé fejlett, mint az ország nyugati fele, a szolgáltatásmutatók (százezer lakosra jutó szolgáltatások száma) jobbak. A települési méret szempontjából a szolgáltatások a legjobb ellátottságot a kisvárosokban mutatják.

Az Anomie as a Thermometer of the Crisis (Experiment) - Social Capacity Phenomenon of the Complex Crisis címü fejezetben Bódi Ferenc, Farkas Jenő és Horváth Zsuzsanna szerzők az egyének és a társadalom egyik legfájdalmasabb problémájára összpontosítanak, a társadalmi értékek elvesztésére, az anómiára. A szerzők eredeti törekvése egy anómiaindex létrehozása volt, amelynek előzményeként a társadalmi kapacitási indexet alkották meg. A szerzők alkalmaz- 
zák Robert Merton anómia koncepcióját, kategorizálják az anómia különböző intenzitási szintjeit és különböző típusait. A mertoni koncepció adaptációja révén kimutatták: ahol a társadalmi integráció gyenge, és a társadalmi kapacitás alacsony, az anómia tünetei konglomerátumként halmozódnak fel. A kísérlet kiterjed Magyarország valamennyi településére, kivéve Budapestet. A komplex társadalmi kapacitásmutató több indikátorból tevődik össze, ilyen a kriminalitás, a kiszolgáltatottak aránya, a jövedelemszint, az adóerö-képesség, a demográfiai dinamika, az abortuszgyakoriság, a korai halálozás aránya. A 2008-as pénzügyi válságra fókuszáló munkájukat, amely 2012-ben jelent meg Brémában (Local Organization of Social Services in Hungary), érdemes lenne megismételni a Covid19 utáni válság hatásának mérésére is, és összevetni a két eredményt.

(Bódi Ferenc - Fábián Gergely - Fónai Mihály - Kurkinen, Jorma - Lawson, Thomas R.-Pietiläinen, Hannu editors: Access to Services in Rural Areas: A Comparison of Finland and Hungary. Bremen: Europäischer Hochschulverlag GmbH \& Co. KG, 2014, 315 o.)

Ralitsa Savova

PhD-jelölt Pécsi Tudományegyetem Interdiszciplináris Doktori Iskola Politikatudományi Program 